\title{
TRASTUZUMAB EFFICACY QUANTIFIED BY FLUORINE-19 MAGNETIC RESONANCE IMAGING
}

\author{
DOROTA BARTUSIK-AEBISHER ${ }^{1 *}$, DAVID AEBISHER ${ }^{1}$, ANNA CZMIL $^{2}$ \\ and DAMIAN MAZUR ${ }^{2}$
}

\author{
${ }^{1}$ Medical College of The University of Rzeszow, 2A Kopisto St., 35-959 Rzeszow, Poland \\ ${ }^{2}$ Faculty of Electrical and Computer Engineering, Rzeszow Polytechnic, \\ 2 Wincentego Pola St., 35-959 Rzeszow, Poland
}

\begin{abstract}
The purpose of this study was to conjugate Trastuzumab with fluorine-bearing PAMAM dendrimer to compare activities in three-dimensional (3D) cultured breast cancer cells with parent Trastuzumab. An in vitro study was performed to determine cellular responses to fluorinated Trastuzumab conjugates by Magnetic Resonance Imaging (MRI). Breast cancer cells were cultured in 3D geometry. Proton ( $\left.{ }^{1} \mathrm{H}\right) \mathrm{MRI}$ and Fluorine$19\left({ }^{19} \mathrm{~F}\right)$ MRI were used for visualization of cellular locations within a Hollow Fiber Bioreactor (HFBR) device and to monitor the cellular response to treatment. The results of this study confirm that cell growth is significantly decreased following treatment with Trastuzumab conjugates. The use of fluorinated Trastuzumab conjugates decreases breast cancer cell growth in 3D cultures and allows for tracking of drug delivery to cancer cells via ${ }^{19} \mathrm{~F}$.
\end{abstract}

Keywords: Magnetic Resonance Imaging, breast cancer cells, three-dimensional cell culture, trastuzumab, trastuzumab conjugates

The effectiveness of anticancer therapy can be improved by non-invasive visualization of changes in tissue and cells before and after treatment. Here, we have measured the time course of MCF-7 breast cancer cell growth noninvasively by ${ }^{19} \mathrm{~F}$ Magnetic Resonance Imaging (MRI) in response to treatment with fluorinated Trastuzumab. MCF-7 cells were cultured in a Hollow Fiber Bioreactor (HFBR) device to obtain 3D growth of cells mimicking breast cancer tumor volume (1). In the next step, we applied MRI to examine the effect of administration of Trastuzumab alone and Trastuzumab conjugated with fluorinated and non-fluorinated dendrimer formulations in the $3 \mathrm{D}$ cell cultures. Trastuzumab is a targeting antibody known to target the HER-2 receptor in HER-2 overexpressing MCF-7 cells. One objective of this study was to determine differences in cellular delivery between Trastuzumab alone and Trastuzumab conjugated to fluorinated and non-fluorinated conjugates by MRI. Here, we demonstrate the suitability of an MRI assay to noninvasively track the treatment response in MCF-7 cancer cells. Trastuzumab treatments effectively shorten the lon- gitudinal $\left(\mathrm{T}_{1}\right)$ and transverse relaxation time $\left(\mathrm{T}_{2}\right)$ of protons through changes in cellular water content resulting in both $T_{1}$ and $T_{2}$ contrast Differences in $T_{1}$ and $T_{2}$ allow for differentiation between untreated cell culture and treated cultures containing proteinbound receptors (2).

It is known that dendrimers can be used as carriers of anti-cancer drugs. Dendrimers are organic compounds with a very regular structure consisting of a core and radiating branches. Dendrimers can be associated with the monoclonal antibody Trastuzumab and serve as a delivery vehicle to cell receptors and serve as a reporter. Dendrimers can transport a drug in two ways: by covalently binding drug molecules to surface amine groups of the dendrimer or drugs can be encapsulated in spaces between branches (3). Dendrimers can carry many substances for both therapy and diagnostics including fluorescent markers, photosensitizers, or monoclonal antibodies as reported here. The presence of a large number of amine groups on the surface of the dendrimer creates a myriad of possibilities for synthesizing dendrimer-drug conjugates that have a

\footnotetext{
* Corresponding author: dbartusik-aebisher@ur.edu.pl
} 
direct impact on increasing the effectiveness of therapy and minimizing its toxic effects on normal cells (4).

Trastuzumab dendrimer conjugates offer advantages in addition to tracking such as protection from premature clearance and this advantage may lead to a reduction in dose without compromising therapeutic effect. Direct release of Trastuzumab dendrimer conjugates within a tumor microenvironment reduces cytotoxicity in healthy cells (5). Trastuzumab-dendrimer conjugates are also effectively transported to cancer cells which have been confirmed by viability tests and ${ }^{19} \mathrm{~F}$ MRI. The utility of antibodies for in vitro applications (6), cancer therapeutics (7-10), and in tumor MRI (11) has been reported.

Detection and tracking of Trastuzumab by MRI can be accomplished by attaching ${ }^{19} \mathrm{~F}$-labeled conjugates. In addition to ${ }^{19} \mathrm{~F}$, incorporation of ${ }^{13} \mathrm{C}$ and ${ }^{15} \mathrm{~N}$ nuclei into biopharmaceuticals also enables tracking by eliminating background tissue signals $(12,13)$. The images obtained by multinuclear MRI can be combined with ${ }^{1} \mathrm{H}$ MRI images to improve tumor visualization (14).

\section{EXPERIMENTAL}

\section{Materials}

Human Adenocarcinoma MCF-7 Cell line for cell cultures was supplied from ATCC (American Type Culture Collection (ATCC $\left.{ }^{\circledR}\right)$, Manassas, VA, USA). All compounds for cell cultures were supplied by Fisher Scientific (Oakland, ON, Canada). Trastuzumab (Herceptin) was purchased from Genetech Inc. (San Francisco, CA, USA) Collagen bovine type Lyophilized Fibrous Powder from Tendon (Advanced BioMatrix, USA), Penicillin Streptomycin - Neomycin Solution Stabilized, Fetal Bovine Serum (FBS), Epidermal growth factor (EGF) was from Sigma Aldrich, (Sigma -Aldrich, USA). Growth media for cells were prepared under sterile conditions in a laminar airflow chamber. For development of the 3D cell culture, we employed a Hollow Fiber Bioreactor (FiberSystem Cell Inc., Frederic, MD). All organic solvents and PAMAM dendrimers were purchased from (Sigma Aldrich Company Ltd., Dorset, United Kingdom).

\section{Cell culture}

Human Gland Mammary Adenocarcinoma Cells (MCF-7) with HER-2 overexpression were grown in two-dimensional standard cell cultures until a density of $0.5 \times 10^{5}$ cells $/ \mathrm{mL}$ was achieved (15). To obtain this cell density, $\mathrm{CO}_{2}$ independent medium (Gibco/Invitrogen Corp.) supplemented with $10 \%$ FBS, $1 \%$ L-Glutamate, and $1 \%$ antibiotic (penicillin/streptomycin) was used. A total of 24 bioreactors were used for the study of MCF-7 cells, 3 bioreactors were set up for control MCF-7 cell growth, and 21 bioreactors were used for 7 selected drug concentrations of Trastuzumab, Trastuzumabdendrimer, and Trastuzumab ${ }^{19} \mathrm{~F}$ fluorinated dendrimer conjugates. HER-2 overexpression was confirmed by cytometric analysis (15). Cell counting was done using a hemacytometer. MCF-7 cells $\left(0.5 \times 10^{5}\right.$ cells $\left./ \mathrm{mL}\right)$ were seeded in the HFBR. The bioreactor is a closed-loop system comprised of a $100 \mathrm{~mm}$ polysulfone tube with one fiber. The polysulfone fiber was coated with $10 \mathrm{~mL}$ of collagen solution (1 mg collagen per $1 \mathrm{~mL}$ of phosphatebuffered saline (PBS) and $10 \mathrm{~mL}$ of fibronectin solution ( $10 \%$ in culture media). We used a collagen solution to create an extracellular matrix between the cells and the fiber. To mimic in vivo like conditions, we attempted to use fibronectin including collagen solutions. After the inoculation, the HFBR device was perfused using a peristaltic pump. The flow of medium was adjusted at the rate of $5 \mathrm{~mL} / \mathrm{min}$ and gradually increased to $14 \mathrm{~mL} / \mathrm{min}$. The $\mathrm{pH}$ was maintained between 6.8 and 7.0 in the extra capillary space throughout the duration of experiments. The perfusion medium was changed weekly when the glucose level reached $2 \mathrm{~g} / \mathrm{L}$ as measured with a glucometer. Once cells reached a density of $10^{9}$ cells $/ \mathrm{mL}$ (4 weeks), they were used for treatment with Trastuzumab and Trastuzumab conjugates such as Trastuzumab-dendrimer and Trastuzumab ${ }^{19} \mathrm{~F}$ drug conjugates. At the same time, control MCF-7 cells were grown that were left untreated. The number of cells was determined using the Trypan blue exclusion method (15). Next, the perfused bioreactor was installed within the MRI magnet. Following drug administration ex vivo, ${ }^{19} \mathrm{~F}$ MRI was applied for cell imaging to measure cell viability and to study drug efficacy over $72 \mathrm{~h}$ periods. Throughout the MRI experiments, the HFBR device was maintained under incubator-like conditions $\left(37^{\circ} \mathrm{C}, 5 \% \quad \mathrm{CO}_{2}\right.$ and $95 \%$ air). The installed bioreactor was maintained to keep cells viable under analysis. In addition, ${ }^{19} \mathrm{~F}$ MRI imaging parameters such as resolution, signal to noise ratio, repetition time, and time to echo was determined and optimized. ${ }^{19} \mathrm{~F}$ imaging parameters were matched to the concentration of Trastuzumab-dendrimer-fluorine administered and cell number in the bioreactor. The HFBR device was connected to a reservoir bottle and placed within the MRI-compatible incubation chamber that was continuously flushed with a mix- 
ture of air and $\mathrm{CO}_{2}$. Region of Interest (ROI) was mapped for the 3D tumor cells before treatment.

Treatment with Trastuzumab, Trastuzumab-dendrimer, and Trastuzumab ${ }^{19} \mathbf{F}$ fluorinated dendrimer conjugates

To optimize the binding of Trastuzumab, Trastuzumab-dendrimer and Trastuzumab ${ }^{19} \mathrm{~F}$ fluorinated dendrimer conjugates with cell surface HER2 receptor, cell cultures were grown in the HFBR device and were treated for $24,48,72,96$ and $110 \mathrm{~h}$ (1, 2, 3, 4 and 5 days). The treatment was performed with seven concentrations of Trastuzumab, Trastuzumab-dendrimer and Trastuzumab ${ }^{19} \mathrm{~F}$ conjugates. The concentration of Trastuzumab drug was the same in corresponding Trastuzumab dendrimer and Trastuzumab ${ }^{19} \mathrm{~F}$ conjugates. In total we used bioreactors for seven concentrations of Trastuzumab in three forms: pure drug, Trastuzumab dendrimer and Trastuzumab ${ }^{19} \mathrm{~F}$ conjugates were used in this study. Additionally, each treatment was repeated three times. The formulation of Trastuzumab dendrimer conjugate was composed of $20 \%$ (v/v) of G5PAMAM, 2\% (w/v) safflower oil and $1.7 \%(\mathrm{w} / \mathrm{v})$ glycerin, with water comprising the balance. G5PAMAM was dissolved in anhydrous dimethyl sulfoxide (DMSO) at a final concentration of $5 \mathrm{mg} / \mathrm{mL}$ (12). For the formulation of Trastuzumab ${ }^{19} \mathrm{~F}$ conjugates, ten milligrams of dendrimer (G5-PAMAM) were desiccated in a glass scintillation vial. Compound G5-PAMAM was then dissolved in anhydrous dimethyl sulfoxide (DMSO) at a final concentration of $5 \mathrm{mg} / \mathrm{mL}$. This solution was charged with 1 molar equivalent of triethylamine and 3 molar equivalents of heptafluorobutyric acid anhydride (HFAA). The reaction mixture is agitated vigorously for $2 \mathrm{~h}$ at $25^{\circ} \mathrm{C}$. The corresponding concentration of Trastuzumab in each sample of Trastuzumab-dendrimer and Trastuzumab ${ }^{19} \mathrm{~F}$ dendrimer conjugate was 0.05 (T1), 0.5 (T2), 50 (T3), 100 (T4), 200 (T5), 500 (T6) 1000 (T7) $\mu \mathrm{g} / \mathrm{mL}$ respectively. Based on this calculation, aqueous solutions of Trastuzumab dendrimer were used at concentrations of $0.067 \mu \mathrm{g} / \mathrm{mL}$ (T1D), $0.66 \mu \mathrm{g} / \mathrm{mL}$ (T2D), $66.25 \mu \mathrm{g} / \mathrm{mL}$ (T3D), $132.5 \mu \mathrm{g} / \mathrm{mL}$ (T4D), $265 \mu \mathrm{g} / \mathrm{mL}$ (T5D), $662.5 \mu \mathrm{g} / \mathrm{mL}$ (T6D) and 1325 $\mu \mathrm{g} / \mathrm{mL}$ (T7D) administered to $10^{9}$ cells $/ \mathrm{mL}$ in the $3 \mathrm{D}$ culture ( $\mathrm{n}=3$ cultures for each treatment). Aqueous solutions of Trastuzumab ${ }^{19} \mathrm{~F}$ conjugates were used at concentrations of $0.067 \mu \mathrm{g} / \mathrm{mL}$ (T1F), $0.66 \mu \mathrm{g} / \mathrm{mL}$ (T2F), 66.25 $\mu \mathrm{g} / \mathrm{mL}$ (T3F), $132.5 \mu \mathrm{g} / \mathrm{mL}$ (T4F), 265 $\mu \mathrm{g} / \mathrm{mL}$ (T5F), $662.5 \mu \mathrm{g} / \mathrm{mL}$ (T6F) and $1325 \mu \mathrm{g} / \mathrm{mL}$ (T7F) administered to $10^{\circ}$ cells $/ \mathrm{mL}$ in the $3 \mathrm{D}$ culture $\left(n=3\right.$, for each treatment). For the treatment of $10^{9}$
MCF-7 cells/ml in the HFBR device ( $n=3$, for each treatment, Trastuzumab-dendrimer treatment with Trastuzumab (for controls) and Trastuzumab-dendrimer and Trastuzumab ${ }^{19} \mathrm{~F}$ conjugates: $10 \mathrm{~mL}$ of Trastuzumab at concentrations of $0.05 \mu \mathrm{g} / \mathrm{mL}$ (T1), $0.5 \mu \mathrm{g} / \mathrm{mL}$ (T2), $50 \mu \mathrm{g} / \mathrm{mL}$ (T3), $100 \mu \mathrm{g} / \mathrm{mL}$ (T4), $200 \mu \mathrm{g} / \mathrm{mL}$ (T5), $500 \mu \mathrm{g} / \mathrm{mL}$ (T6) and $1000 \mu \mathrm{g} / \mathrm{mL}$ (T7) was used to treat $10^{\circ}$ cells/mL in HFBR device ( $\mathrm{n}=3$, for each treatment).

\section{Determination and visualization of cellular uptake of treatment}

Before treatment, ${ }^{1} \mathrm{H}$ MR images of MCF-7 cells were performed using a spin-echo imaging sequence with $\mathrm{TR}=1000 \mathrm{~ms}$, TE $=40 \mathrm{~ms}, 0.5 \mathrm{~mm}$ slice thickness, $2 \mathrm{~cm} \times 2 \mathrm{~cm}$ field of view, $256 \times 256$ matrix size and 10 signal averages. After treatment, ${ }^{19} \mathrm{~F}$ MRI images were acquired using a spin-echo imaging sequence with $\mathrm{TR}=500 \mathrm{~ms}, \mathrm{TE}=18 \mathrm{~ms}$, $2 \mathrm{~cm} \times 2 \mathrm{~cm}$ field of view, $256 \times 256$ matrix size and 10 signal averages. ${ }^{1} \mathrm{H}$ and ${ }^{19} \mathrm{~F}$ MRI will be processed with MAREVISI post-processing software. MCF-7 cells $\left(10^{\%} / \mathrm{mL}\right)$ in the HFBR device $(\mathrm{n}=3$ for each treatment) with Trastuzumab, Trastuzumab-dendrimer and Trastuzumab ${ }^{19} \mathrm{~F}$ dendrimer conjugates. The number of treated cells was estimated using regression data of ${ }^{19} \mathrm{~F}$ MRI. ${ }^{19} \mathrm{~F}$ MRI was performed to determine the efficacy of fluorinated derivatives. A positive treatment effect increases ${ }^{19} \mathrm{~F}$ signal intensity (SI) on MR images or spectra. An increase in SI is expected to correlate with increasing cellular uptake of fluorinated dendrimers. ${ }^{19} \mathrm{~F}$ MR images were acquired using a spin-echo imaging sequence with $\mathrm{TR}=500 \mathrm{~ms}$, echo time $\mathrm{TE}=18 \mathrm{~ms}, 0.5 \mathrm{~mm}$ slice thickness, $2 \mathrm{~cm} \times 2 \mathrm{~cm}$ field of view, $256 \times 256$ matrix size and 10 signal averages. The images and spectra were collected 24, 48, 72, 96, $120 \mathrm{~h}$ after treatment in the 3D cell culture. For an internal MR standard, a small capillary with $10 \mu \mathrm{L}$ of $5 \% \mathrm{v} / \mathrm{v}$ trifluoroacetic acid (TFA) was used. The concentration of ${ }^{19} \mathrm{~F}$ was estimated using ${ }^{19} \mathrm{~F}$ (SI) based on reference TFA. ${ }^{19} \mathrm{~F}$ MRS was acquired using a onepulse sequence (flip angle $60^{\circ}$; repetition time (TR) $=800 \mathrm{~ms}$; number of average 2 ; echo time $(\mathrm{TE})=6$ $\mathrm{ms})$. Due to different chemical environments, fluorine signals varied for fluorine alone, fluorinated dendrimer alone, and Trastuzumab-dendrimer-fluorine conjugates attached to the HER- 2 receptor. The HFBR device contained $10^{2}, 10^{3}, 10^{4}, 10^{5}, 10^{6}, 10^{7}$, $10^{8}$ and $10^{9} \mathrm{MCF}-7$ cells with HER-2 overexpression. The overexpression of HER-2 was measured by flow cytometry. The cells were treated with T1-7 Trastuzumab ${ }^{19} \mathrm{~F}$ dendrimer conjugates. The total volume of the HFBR was $10 \mathrm{~mL}$. The ${ }^{19} \mathrm{~F}$ SI was 

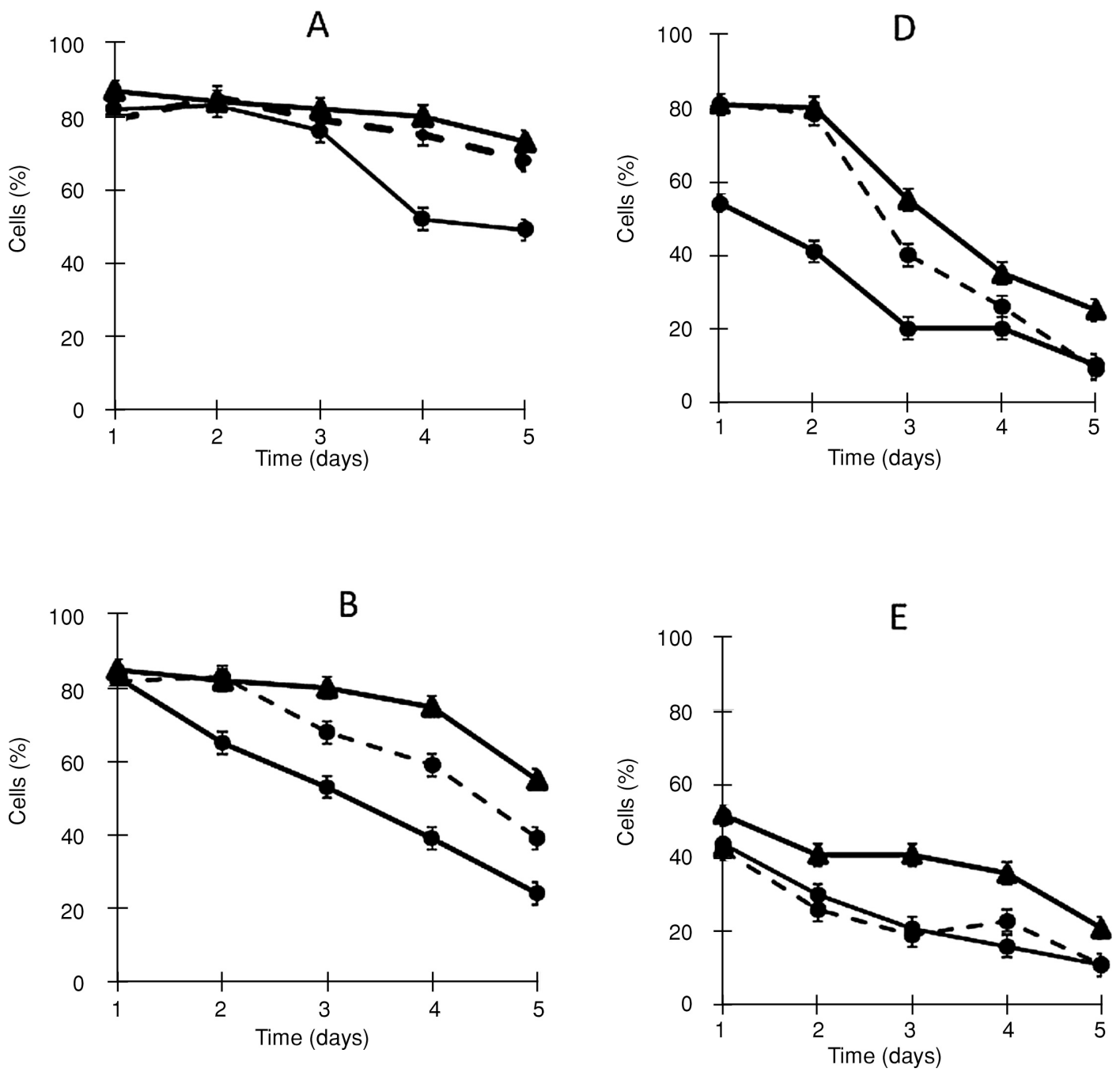

Figure 1A-1G. The decrease in viability (Cells \%) of cells as a function of Time (days) after 1, 2, 3, 4 and 5 days of treatment with 0.05 (1A), 0.5 (1B), 50 (1C), 100 (1D), 200 (1E), 500 (1F), and $1000 \mu \mathrm{g} / \mathrm{mL}$ (1G) Trastuzumab (black solid line, black triangles), Trastuzumabdendrimer (black dashed line, black circles) and Trastuzumab ${ }^{19} \mathrm{~F}$ fluorinated dendrimer conjugate (black solid line, black circles).

measured for each number of cells and each concentration. The calibration curves were prepared as ${ }^{19} \mathrm{~F}$ SI is linearly related to the number of cells treated in HFBR device (16-20).

For calibration, $10 \mathrm{~mL}$ of fluorinated derivates was introduced into a separate HFBR device without cells and MRI scans were performed. ${ }^{19} \mathrm{~F}$ SI was measured directly from an axial slice of the HFBR device. The changes in ${ }^{19} \mathrm{~F}$ SI at different fluorinated derivates concentrations were observed and calibration curves prepared as ${ }^{19} \mathrm{~F}$ SI is linearly related to the amount of ${ }^{19} \mathrm{~F}$ molecules. The ${ }^{19} \mathrm{~F}$ SI of pure HFAA was considered as $100 \%$ of SI. Percentage change in ${ }^{19} \mathrm{~F}$ SI was normalized to pure HFAA using the following equation: ${ }^{19} \mathrm{~F}$ SI $(\%$ change $)=$
$[(\mathrm{U}-\mathrm{L}) / \mathrm{U}] \times 100 \%$, where $\mathrm{L}={ }^{19} \mathrm{~F}$ SI of ${ }^{19} \mathrm{~F}$ in emulsions of fluorinated derivatives (20).

Before treatment, ${ }^{1} \mathrm{H}$ MRI was performed to determine the shape and location of the $3 \mathrm{D}$ cell culture in the HFBR device which is our region of interest. Using MRI software, this region of interest was mapped. The $3 \mathrm{D}$ cell culture in the HFBR device was then treated for $72 \mathrm{~h}$. After $72 \mathrm{~h},{ }^{1} \mathrm{H}$ MRI and ${ }^{19} \mathrm{~F}$ MRI was performed. The region of interest was mapped from both scans. The ${ }^{1} \mathrm{H}$ MRI image showed the 3D cell culture without any signal of fluorine. MRI showed SI only from treated cells and the location of fluorinated derivatives. By subtracting the ${ }^{19} \mathrm{~F}$ MRI region of interest from the ${ }^{1} \mathrm{H}$ MRI region of interest the location of untreated 

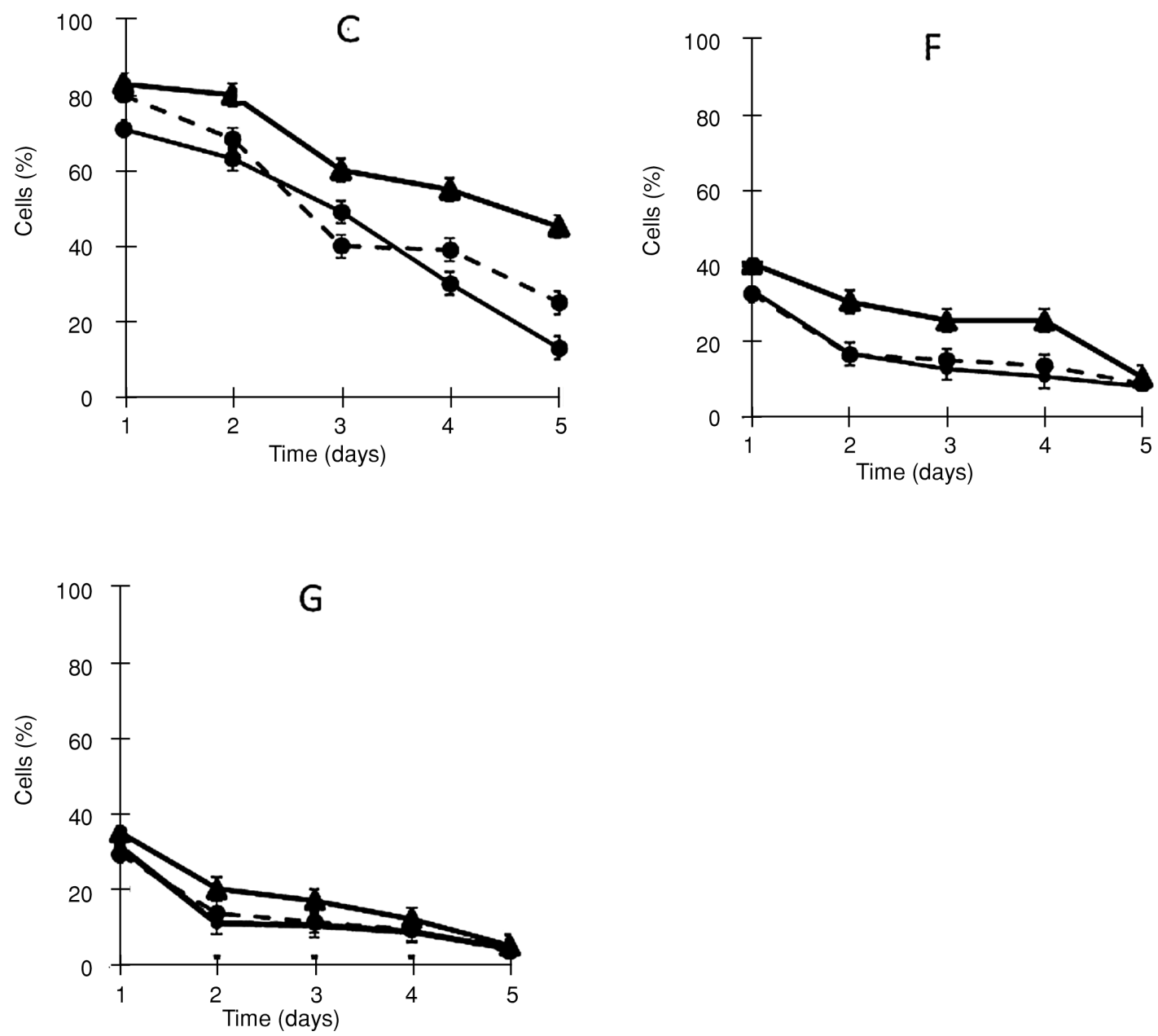

Figure 1A-1G. Continued.

cells in the $3 \mathrm{D}$ culture was determined. All results are expressed as a mean $\pm \mathrm{SD}$. The $3 \mathrm{D}$ ex vivo aggregation of the cells in the bioreactor was imaged using ${ }^{1} \mathrm{H}$ MRI. For imaging, the HFBR connected to a reservoir bottle was placed within the MRI compatible chamber with a continuous flow of air and $\mathrm{CO}_{2}$ mixture while in the magnet. Throughout the data acquisition, HFBR was maintained in $95 \%$ air atmosphere with $5 \% \mathrm{CO}_{2}$ at $37^{\circ} \mathrm{C}$. The MRI experiments were performed using a 9.4 Tesla with $21 \mathrm{~cm}$ bore magnet (Magnex, England) equipped with TMX console (NRC-IBD, Canada). ${ }^{1} \mathrm{H}$ MR images were acquired using a transmit/receive RF volume coil operating at 400 MHz. The spin-echo images were acquired with a repetition time $(\mathrm{TR})=5000 \mathrm{~ms}$, echo time $(\mathrm{TE})=$ $12.8 \mathrm{~ms}, \mathrm{FOV}=3 \mathrm{~cm} \times 3 \mathrm{~cm}$, slice thickness $1 \mathrm{~mm}$, and matrix $256 \times 256$. Based on MR images the cells samples $\left(>10^{9}\right.$ cells $\left./ \mathrm{mL}\right)$ were harvested with a syringe from the region close to the fiber, washed three times with PBS and centrifuged. To determine the volume of cells, a Region of Interest (ROI) was drawn around the region of the tumor cells before treatment.

\section{Statistical analysis}

Results are presented as the mean \pm standard deviation (SD) based on three independent experiments. Statistical analysis was done by one-way analysis of variance (ANOVA) using Statistica 10.0 software (StatSoft, Kraków, Poland). A probability level of $P<0.05$ was considered significant.

\section{RESULTS AND DISCUSSION}

Trastuzumab, Trastuzumab dendrimer and Trastuzumab ${ }^{19} \mathrm{~F}$ conjugates were added to $3 \mathrm{D}$ cell cultures and cell viability was measured after treat- 
ment. The data shown in Figure 1 presents changes in the viability of the cells treated with different drug concentrations during 1-5 days of treatment, respectively Figure $1 \mathrm{~A}-1 \mathrm{G}$. The viability at each time point of the treatment was calculated from 3 separate measurements and averaged by standard calculations. After 1 day, the viability of MCF-7 cells treated with $0.05 \mu \mathrm{g} / \mathrm{mL}$ of Trastuzumab, Trastuzumab dendrimer and Trastuzumab ${ }^{19} \mathrm{~F}$ dendrimer conjugate was $87 \pm 2 \%$ and $82 \pm 3 \%$ and 79 $\pm 5 \%$, respectively (Fig. $1 \mathrm{~A}$ ). After 3 days, the viability of cells treated with $0.05 \mu \mathrm{g} / \mathrm{mL}$ concentrations of Trastuzumab, Trastuzumab-dendrimer and Trastuzumab ${ }^{19} \mathrm{~F}$ fluorinated dendrimer conjugate was $82 \pm 3 \%, 80 \pm 3 \%$ and $76 \pm 3 \%$ respectively (Fig. 1A). After 5 days, viability of cells was $73 \pm$ $3 \%, 68 \pm 3 \%$ and $49 \pm 3 \%$ respectively (Fig. 1A). This result indicated that the conjugate of Trastuzumab with ${ }^{19} \mathrm{~F}$ dendrimer is $3 \pm 1 \%$ more efficient than the conjugate of Trastuzumab with dendrimer and $8 \%$ more efficient in cell killing than Trastuzumab alone. After 1 day of treatment, the highest concentrations of Trastuzumab (1000 $\mu \mathrm{g} / \mathrm{mL}$ ) showed $24 \pm 2 \%$ and $5 \pm 2 \%$ less difference in viability decrease compared to Trastuzumab ${ }^{19} \mathrm{~F}$ dendrimer conjugates and Trastuzumab dendrimer conjugates, respectively. All seven plots (1A to $1 \mathrm{G}$ in Fig. 1) showed that the mixture of Trastuzumab with dendrimer in the presence of ${ }^{19} \mathrm{~F}$ is the treatment with the lowest MCF-7 viability. The decrease in viability after 1, 2, 3, 4 and 5 days of treatment with Trastuzumab (black solid line, black triangles), Trastuzumab-dendrimer (black dashed line, black circle) and Trastuzumab $-{ }^{19} \mathrm{~F}$ fluorinated dendrimer conjugate (black solid line, black circle) are higher with increased concentration of Trastuzumab. The use of Trastuzumab concentration in the range of $0.05 \mu \mathrm{g} / \mathrm{mL}-1000 \mu \mathrm{g} / \mathrm{mL}$ showed a range of viable
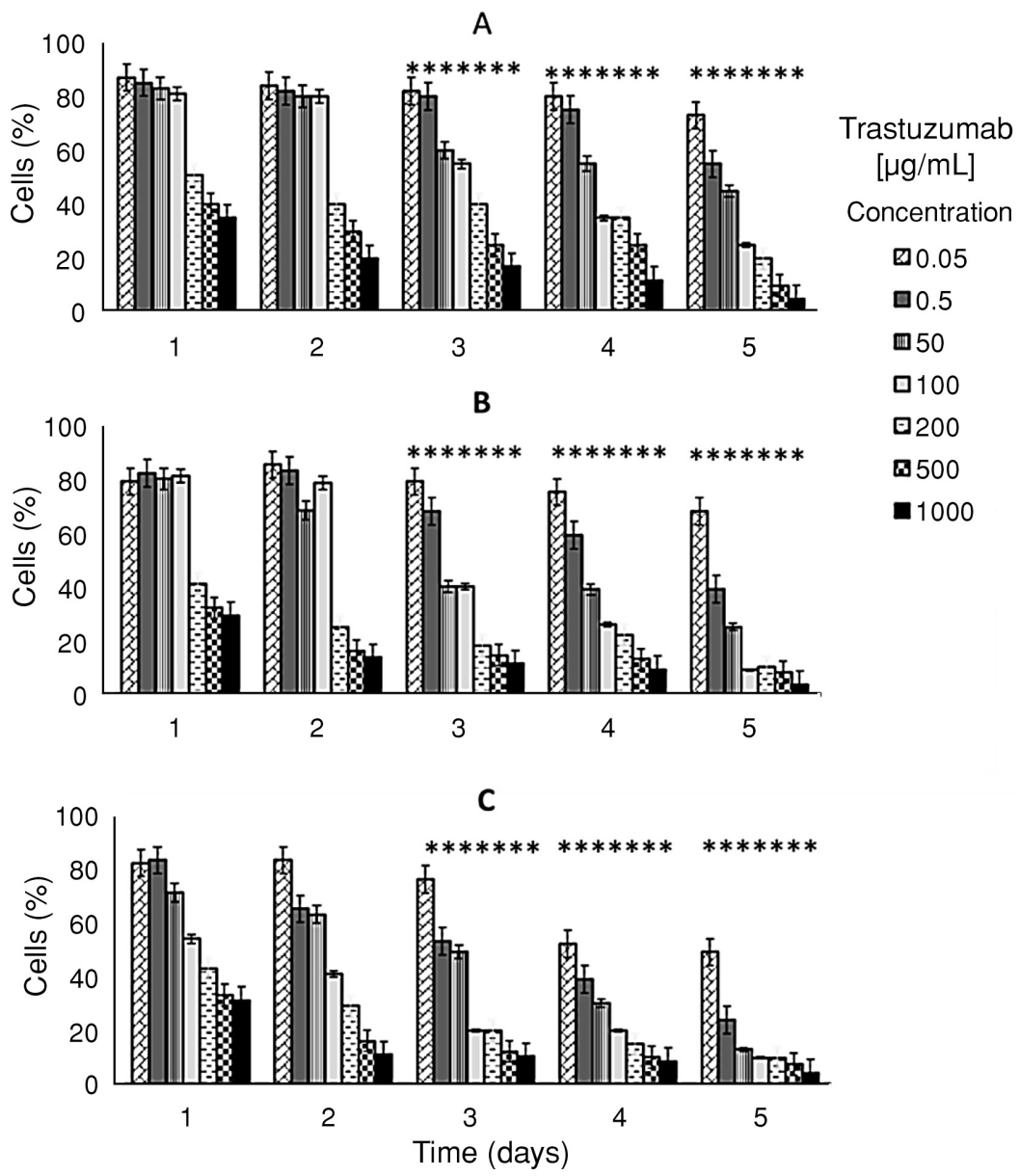

Figure $2 \mathrm{~A}-2 \mathrm{C}$. The decrease in viability (Cells $\%$ ) as a function of Time (days) after 1, 2, 3, 4 and 5 days of treatment with $0.05,0.5,50$, 100, 200, 500, and $1000 \mu \mathrm{g} / \mathrm{mL}$ Trastuzumab (2A), Trastuzumab-dendrimer (2B) and Trastuzumab fluorinated conjugate (2C). Significant results are indicated with a star. 

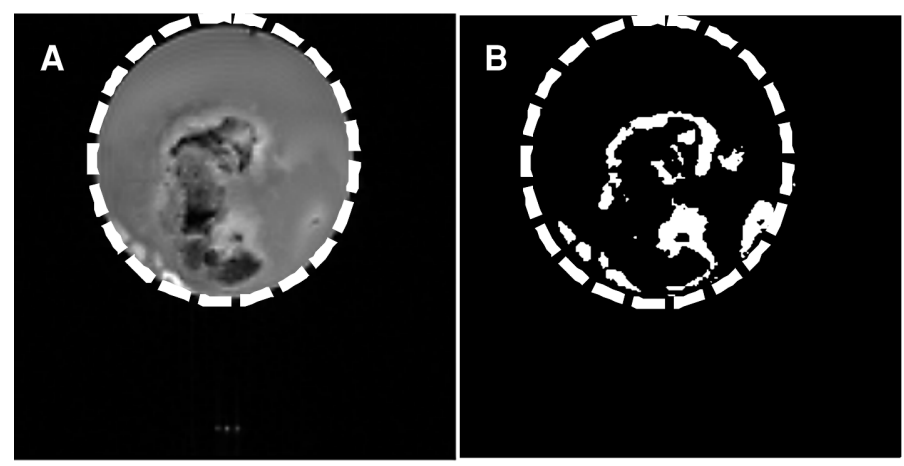

Figure 3A-3B. An axial slice from ${ }^{1} \mathrm{H}$ MRI of untreated MCF-7 cells in the HFBR device. The white dashed line indicates the diameter of the HFBR (3A). An axial slice from ${ }^{19} \mathrm{~F}$ MRI $\left({ }^{19} \mathrm{~F}\right.$ SI $\left.=95 \%\right)$ of MCF-7 cells in the HFBR treated with Trastuzumab ${ }^{19} \mathrm{~F}$ dendrimer conjugates after 5 days and acquired using a spin-echo imaging sequence: $\mathrm{TR}=500 \mathrm{~ms}$, TE $=18 \mathrm{~ms}, 0.5 \mathrm{~mm}$ slice thickness, $2 \mathrm{~cm} \times 2 \mathrm{~cm}$ field of view, $256 \times 256$ matrix size and 10 signal averages $(3 \mathrm{~B})$.

cells from $87 \pm 1 \%$ to $5 \pm 1 \%$. For Trastuzumab dendrimer conjugates this range was $82 \pm 2 \%$ to $4 \pm 1 \%$ and Trastuzumab ${ }^{19} \mathrm{~F}$ dendrimer is $79 \pm 2 \%$ to $3.5 \pm$ $1 \%$. The differences between groups are significant after three days of treatment for cells treated with $0.05 \mu \mathrm{g} / \mathrm{mL}$ of Trastuzumab in (T1), (T1D), (T1F); $0.5 \mu \mathrm{g} / \mathrm{mL}$ of Trastuzumab in (T2), (T2D), (T2F); 50 $\mu \mathrm{g} / \mathrm{mL}$ of Trastuzumab in (T3), (T3D), (T3F); 100 $\mu \mathrm{g} / \mathrm{mL}$ of Trastuzumab in (T4), (T4D), (T4F); 200 $\mu \mathrm{g} / \mathrm{mL}$ of Trastuzumab in (T5), (T5D), (T5F); 500 $\mu \mathrm{g} / \mathrm{mL}$ of Trastuzumab in (T6), (T6D), (T6F) and $1000 \mu \mathrm{g} / \mathrm{mL}$ of Trastuzumab in (T7), (T7D), (T7F). Treatment with $0.5 \mu \mathrm{g} / \mathrm{mL}$ of Trastuzumab, Trastuzumab-dendrimer and Trastuzumab ${ }^{19} \mathrm{~F}$ fluorinated dendrimer, showed that after 1 day of treatment, cell viability was $86 \pm 1 \%, 82 \pm 1 \%$ and 70 $\pm 2 \%$, respectively (Fig. $2 \mathrm{~A}$ ); after 3 days $80 \pm 3 \%$, $78 \pm 3 \%$ and $65 \pm 3 \%$; and after 5 days $55 \pm 3 \%$, $39 \pm 3 \%$ and $24 \pm 3 \%$. After treatment with 50 $\mu \mathrm{g} / \mathrm{mL}$, the viability of cells after 1 day was 83 $\pm 3 \%, 80 \pm 3 \%$ and $71 \pm 3 \%$. After 3 days viability decreased to $68 \pm 3 \%, 60 \pm 3 \%$ and $49 \pm 3 \%$ and after 5 days of treatment $45 \pm 3 \%, 28 \pm 3 \%$ and 13 $\pm 3 \%$. The use of $100 \mu \mathrm{g} / \mathrm{mL}$ of Trastuzumab and higher such as $200 \mu \mathrm{g} / \mathrm{mL}, 500 \mu \mathrm{g} / \mathrm{mL}$ and 1000 $\mu \mathrm{g} / \mathrm{mL}$ of Trastuzumab showed a similar decrease in cell viability over time. The decrease of MCF-7 cells viability after treatment with Trastuzumab ${ }^{19} \mathrm{~F}$ dendrimers conjugates (Fig. 2C) was higher than the decrease in viability of MCF-7 cells after treatment with Trastuzumab - dendrimers conjugates (Fig. 2B).

The optimal growth conditions and viability of the $3 \mathrm{D}$ cancer cell cultures in the HFBR device were determined. The 3D cell culture was grown over a 4week time period and cell density varied within the
HFBR device due to the differences in media flow and waste concentration. ${ }^{1} \mathrm{H}$ MRI images were performed on cultures before treatment to show the localization of cells in the HFBR device. Moreover, ${ }^{1} \mathrm{H}$ images allowed us to monitor changes in the localization of cells providing anatomical information on the 3D cell aggregation in the HFBR device. The $3 \mathrm{D}$ culture mimics in vivo conditions and is structurally more similar to a tumor than commonly used cell monolayers. Alternatives to the HFBR in vitro model have been studied as ex vivo models of a primary tumor growing in $3 \mathrm{D}$ HFBR device. In the in vitro tumor environment, our designed Trastuzumab-dendrimer and Trastuzumab- ${ }^{19} \mathrm{~F}$ fluorinated dendrimer conjugate allowed us to confirm selective elimination of cancer cells from the cell culture. A 3D HFBR device supplied nutrients and oxygen to cells and produced high cell density. Thus, the main advantage of using 3D cell cultures in this context is the generation of high tissue densities necessary for MRI assays (15-17). ${ }^{1} \mathrm{H}$ MRI detects the signal from protons in cells and ${ }^{19} \mathrm{~F}$ MRI detects only ${ }^{19} \mathrm{~F}$ nuclei. ${ }^{1} \mathrm{H}$ MRI can be performed with or without a contrast agent. However, the natural ${ }^{19} \mathrm{~F}$ abundance is too low for ${ }^{19} \mathrm{~F}$ MRI detection; however, the uptake of fluorine-containing drugs in cells can be observed without any additional contrast agents. The uptake of fluorinated Trastuzumab conjugates can be monitored by ${ }^{19} \mathrm{~F}$ MRI. After 4 weeks, MCF-7 cells in HFBR reach a suitable density for MRI measurements. Moreover, ${ }^{1} \mathrm{H}$ MRI technique (Fig. 3A) was suitable for multiple, repeated measurements to observe dynamic changes in response to provide noninvasive characteristics of the 3D cell culture.

This project used ${ }^{19} \mathrm{~F}$ MRI to improve visualization of Trastuzumab delivery. The use of mono- 


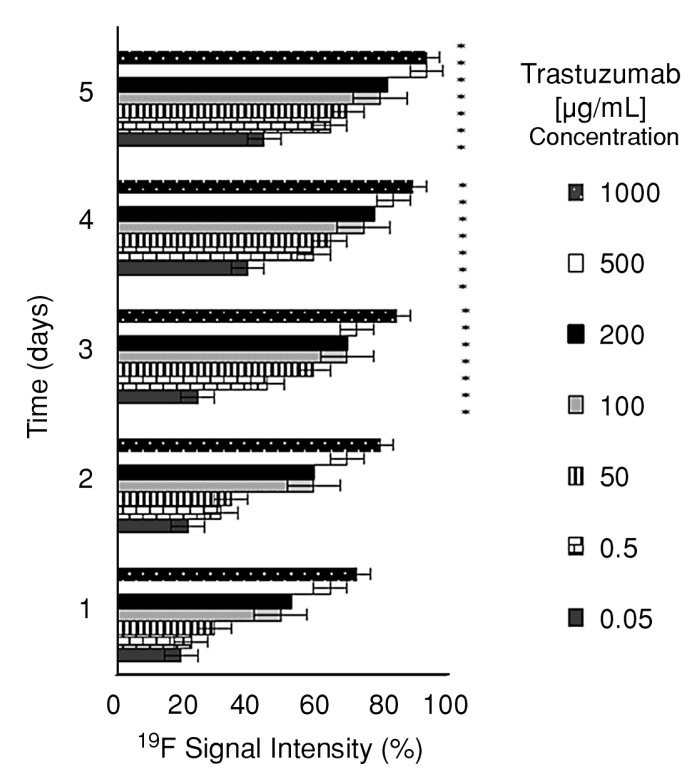

Figure 4. Increase in ${ }^{19} \mathrm{~F}$ signal intensity (\%) as a function of Time (days) after 1, 2, 3, 4 and 5 days during MCF-7 cell treatment with $0.05,0.5,50,100,200,500$, and $1000 \mu \mathrm{g} / \mathrm{mL}$ Trastuzumab fluorinated conjugate.

clonal antibodies in cancer therapy is rapidly advancing. In recent years, the effectiveness of anti-cancer therapy resulting from the combination of properties of monoclonal antibodies and drugs has also demonstrated. To confirm the efficacy of the monoclonal antibody conjugated with dendrimer in in vitro studies Miyano et al. (21) used PAMAM generation 6 modified dendrimers with two amino acids lysine and glutamic acid (KG6E). In the next step, they added AlexaFlour 488 to study the penetration of the conjugate to cells overexpressing HER2 receptors (21). In research done by Cline et al. the synthesis of the PAMAM dendrimer conjugated with paclitaxel was performed (22). Paclitaxel conjugated to $4^{\text {th }}$ PAMAM dendrimer generation (23), $5^{\text {th }}$ PAMAM dendrimer generation (24) and $6^{\text {th }}$ PAMAM dendrimer generation (23) are also known. Baker et al. used the $5^{\text {th }}$ dendrimer PAMAM generation conjugated with trastuzumab and methotrexate. He observed increased penetration of the conjugates into cells and the toxicity of the conjugate against MCA207HER2 breast cancer cells was slightly lower compared to free methotrexate (25). Studies by Pei et al. have shown that conjugates target lysosomes and late endosomes, and released doxorubicin that accumulated in the nucleus of the tumor cell (26). The studies of Yabbarova et al. confirmed the dependence of released doxorubicin on decreasing
$\mathrm{pH}$ (27). Trastuzumab has also been covalently bound to dendrimers bearing isotopes $(28,29)$. It was observed that the conjugate of dendrimer and antibody showed 2-4 times greater activity on SKBR3 cells and 9 times on MDA-MB-231 cells than the antibody itself when combined with radioactive elements (30). The coupling of fluorinated dendrimers with Trastuzumab allows for ${ }^{19} \mathrm{~F}$ Signal Intensity (SI) measurements (Fig. 4) and drug tracking using ${ }^{19} \mathrm{~F}$ MRI. By monitoring ${ }^{19} \mathrm{~F}$ SI intensity, the location of treated cells can be determined where an increase in ${ }^{19} \mathrm{~F}$ SI corresponds to an increase in MCF-7 cell death. The ${ }^{19} \mathrm{~F}$ SI values were dependent on the concentration of cells and fluorine conjugates in the cells treated with Trastuzumab ${ }^{19} \mathrm{~F}$ dendrimer conjugates. ${ }^{19} \mathrm{~F}$ MRI images are highly selective, as only cells treated Trastuzumab ${ }^{19} \mathrm{~F}$ dendrimer conjugates with are visible (Fig. 3B). In this treatment, the fluorinated compounds with low Trastuzumab concentrations of $0.05 \mu \mathrm{g} / \mathrm{mL}$ generate $21 \%$ cell death after 5 days and fluorinated compounds with Trastuzumab concentration of $1000 \mu \mathrm{g} / \mathrm{mL}$ generates $95 \%$ cell death after 5 days of treatment.

\section{CONCLUSIONS}

This work evaluated Trastuzumab conjugates with dendrimers and fluorinated dendrimers in regards to improving the efficacy of $\mathrm{MCF}-7$ cells treatment. The addition of fluorine to Trastuzumab enables the drug uptake to be measured by ${ }^{19} \mathrm{~F}$ MRI. The use of 3D breast cancer cell cultures provided tissue density that mimics in vivo tumor conditions. This project presents an innovative approach towards the application of new Trastuzumab derivatives that are expected to improve efficacy and noninvasive drug visualization. It is anticipated that the results from this research will provide the impetus for the development of an in vivo clinical protocol. The conducted research indicates that the use of conjugates increases the effectiveness of treatment, and also reduces the toxicity of therapeutics to normal cells due to proper drug delivery. The use of Trastuzumab and dendrimers allow for the study of targeted therapy and delivery of a high dose of the drug directly to the cancer cells. Trastuzumab conjugates show the effectiveness of breast cancer cell treatment. However, in order to utilize Trastuzumab conjugates, further studies are required.

\section{Acknowledgments}

Dorota Bartusik-Aebisher acknowledges sup- 
port from the National Center of Science NCN (New drug delivery systems-MRI study, Grant OPUS-13 number 2017/25/B/ST4/02481).

\section{Conflict of interest}

The authors declare no conflicts of interest.

\section{REFERENCES}

1. Bartusik D., Tomanek B., Lattová E., Perreault H., Fallone G.: J. Pharm. Biomed. Anal. 51, 192 (2010).

2. Bartusik D., Tomanek B., Fallone G.: Med. Chem. Res. 19, 1153 (2019).

3. Kaminskas L.M., McLeod V.M., Kelly B.D., Sberna G., Boyd B.J., et al.: Nanomedicine 8, 103 (2012).

4. Madaan K., Kumar S., Poonia N., Lather V., Pandita D.: J. Pharm. Bioallied Sci. 6, 139 (2014).

5. Malik N., Evagorou E.G., Duncan R.: Anticancer Drugs 10, 767 (1999).

6. Roberts J.C., Bhalgat M.K., Zera R.T.: J. Biomed. Mat. Res. 30, 53 (1996).

7. Singh P., Moll F., Lin S.H., Ferzli C., Yu K.S., et al.: Clin. Chem. 40, 1845 (1994).

8. Barth R.F., Adams D.M., Soloway A.H., Alam F., Darby M.V.: Bioconjug. Chem. 55, 58 (1994).

9. Barth R.F., Soloway A.H., Adams D.M., Alam F.: in Progress in Neutron Capture Therapy for Cancer. Allen B.W., Moore D.E., and Harrington B., Eds., pp. 265-268, Plenum Press, New York 1992.

10. Wu C., Brechbiel M.W., Kozak RW., Gansow O.A.: Bioorg. Med. Chem. Lett. 4, 449 (1994).

11. Wiener E.C., Magnin R.L., Gansow O.A.: Magn. Reson. Med. 31, 1 (1994).

12. Bartusik D., Tomanek B., Siluk D., Kaliszan R., Fallone G.: Anal. Biochem. 387, 315 (2009).

13. Duncan R., Malik N.: J. Contr. Rel. Bio. Mat. 23, 105 (1996).
14. Bartusik D., Tomanek B.: Adv. Drug. Deliv. Rev. 65, 1056 (2013).

15. Bartusik D., Tomanek B.: Arch. Biochem. Biophys. 493, 234 (2010).

16. Deutsch C.J., Taylor J.S.: Ann. N.Y. Acad. Sci. 508, 33 (1987).

17. Bartusik D., Tomanek B., Lattová E., Perreault H., Fallone G.: J. Pharm. Biomed. Anal. 51, 192 (2010).

18. Bulte J.W., Wu C., Brechbiel M.W., Brooks R.A., Vymazal J., et al.: Invest. Radiol. 33, 841 (1998).

19. Bartusik D., Tomanek B.: J. Pharm. Biomed. Anal. 51, 894 (2010).

20. Biro G.P., Blais P., Rosen A.L.: Crit. Rev. Oncol. Hemat. 6, 311 (1987).

21. Miyano T., Wijagkanalan T.W., Kawakami S., Yamashita F., Hashida M.: Mol. Pharm. 7, 1318 (2010).

22. Cline E.N., Li M.H., Choi S.K., Herbstman J.F., Kaul N., et al.: Biomacromolecules 14, 654 (2013)

23. Garea S.A., Ghebaur A.: Mater. Plast. 49, 1 (2012).

24. Majoros I.J., Myc A., Thomas T., Mehta C.B., Baker J.R.: Biomacromolecules 7, 572 (2006).

25. Shukla R., Thomas T.P., Desai A.M., Kotlyar A., Park S.J., Baker J.R.: Nanotechnology 19, 295102 (2008).

26. Zhu S., Hong M., Zhang L., Tang G., Jiang Y., Pei Y.: Pharm. Res. 27, 161 (2010).

27. Yabbarov N.G., Posypanova G.A., Vorontsov E.A., Popova O.A., Severin E.S.: Biochemistry 78, 884 (2013).

28. Boerman O.C., van Schaijk F.G., Oyen W.J., Corstens F.H.: J. Nucl. Med. 44, 400 (2003).

29. Rossin R., Verkerk P.R., van den Bosch S.M., Vulders R.C., Verel I., Lub J.: Angew. Chem. Int. Ed. Engl. 49, 3375 (2010).

30. Chan C., Cai Z., Reilly R.: Pharm. Res. 30, 1999 (2013).

(c) 2020 by Polish Pharmaceutical Society. This is an open-access article under the CC BY NC license (c) (1) (9) (http://creativecommons.org/licenses/by-nc/4.0/). 